\title{
Ecological and Geographical Features of Ontogenesis of Holocene Soils of Kamianets-Podilskyi Fortress
}

\author{
Roman Malyk ${ }^{1 *}$, Andriy Kyrylchuk ${ }^{1}$, Zinovy Pankiv ${ }^{1}$, and Ihor Kasiyanyk ${ }^{2}$ \\ ${ }^{1}$ Ivan Franko National University of Lviv, 79000, University str. 1, Lviv, Ukraine \\ ${ }^{2}$ Ivan Ogienko National University of Kamianets-Podilskyi, 32301, Ogienko str. 61, Kamianets-Podilskyi, Ukraine
}

\begin{abstract}
The article analyzes the degree of study of the genetic features of Holocene soils of beligerative complexes. A detailed description of natural and anthropogenic conditions and factors determining the geography, genesis and ecological condition of modern and buried soils of beligerative structures of Kamianets-Podilskyi Fortress is given. Considerable attention is paid to the problem of ontogenesis of the dominant natural and anthropogenic soils within the study area, represented by urborendzins and constructional soils. The morphogenetic features of these soils have been studied. The soils of the beligerative complex are represented by naturally anthropogenic soils - urborendzins and constructional soils. They are polygenetic with complex phylogeny and their genesis includes at least two onogenesis. For a long time soils have been evolving naturally in form of typical rendzin, but have undergone quantitative and qualitative changes due to intensive anthropogenic activity. The genetic profile of soils is characterized by significant variability of morphological traits, the presence of eluvium of soilforming rocks in the entire soil layer. the studied Holocene soils (modern and buried) are an integral part of the historical and cultural lands and need protection, as they contain information about the evolution of the territory and ways of its use.
\end{abstract}

\section{Introduction}

Topicality. The study of the genesis of Holocene soils of beligerative complexes at the present stage of genetic-geographical research is important and arouses interest in the world soil science. This is mainly due to the presence of buried and fossil horizons in the genetic profile of these soils. This allows evolutionary, historical and paleo-soil science to solve the problems of time and evolutionary history by analyzing the genesis and geography of both modern and paleo soils within a single landscape complex with the possibility of accurate dating. The buried soils of beligerative complexes, which usually act as archeological monuments, are buried mainly due to anthropogenic influence. Consequently, they are well isolated from the digenetic action of modern soil-forming processes, in contrast to the relict features in the profile of modern soils. Holocene soils are better preserved because they were not subjected to pedometamorphic processes of the periglacial zone of the Pleistocene-Holocene, which distinguishes them from fossilized soils of the Pleistocene[1]. These genetic features make it possible to form fair presentation about the presence in the soil of signs of different age generations of all stages of its ontogenesis, from the parent breed to modern periods of soil life.

Soil evolution data contain information about the evolution of the territory of its formation and ways of its use. The genetic profile of the soil encodes information about the history of development and the course of landscape evolution in general, which in turn makes it possible to carry out reconstructions of paleolandscapes.

The purpose of the study is to study the genetic features of Holocene soils of the beligerative complex of Kamianets-Podilskyi Fortress. To achieve this goal it is necessary to solve the main objectives of the study: to analyze the degree of study of genetic features of Holocene soils of beligerative complexes, to characterize natural and anthropogenic conditions and factors influencing the geography, genesis and ontogenesis of modern and buried soils of investigated beligerative structures; to highlight the features of the genetics of the studied soils, to consider the complexity of the ontogenesis of natural and anthropogenic soils, represented by urborendzins and constructional soils within the study area.

The object of research is Holocene soils: urborendzins and constructional soils of the Old Castle of Kamianets-Podilskyi Fortress.

The subject of research is morphogenetic features of the studied Holocene soils at different stages of ontogenesis.

The following scientific methods were used while investigating the genetic features of Holocene soils of beligerative structures on the territory of KamianetsPodilskyi Fortress: cartographic (when choosing the place for laying the sections, the following were used: the plan-scheme of the territory of the museum-reserve Kamyanets-Podilsky State Historical Museum-Reserve

* Corresponding author: derevokpkm1@gmail.com 
(scale 1: 1000); large-scale topographic map (scale 1: 10000)), informational (analysis of materials on geomorphology, geological and tectonic structure, hydrogeology and historical and local lore archival materials of the museum-reserve), problemchronological (study of soil evolution under the influence of the functioning of the beligerative complex), comparative-geographical (substantiation of conclusions about the genesis of soils and patterns of their location on the basis of comparison of soils and relevant factors of soil formation in their historical development and location), archeological with morphological-genetic, ecological-genetic and systemic approaches and evolutionary paradigm of soil formation.

\section{Analysis of recent research and publications}

Many research works have been done recently to study the genesis of Holocene soils of beligerative complexes. Most of the published monographs and articles deal with the genesis of buried and fossil soils of beligerative complexes in the context of paleopedological, geoarchaeological and paleobotanical research. Analyzing recent publications, it was established that the genetic features of Holocene soils of beligerative complexes are actively studied by scientists of evolutionary, evolutionary-genetic, historical soil science and anthropogenic landscape science. Genetic features of Holocene soils of beligerative complexes (archeological monuments) are considered thoroughly in the works of S. P. Pozniak, Y. M. Dmitruk, J. M. Matviishina, M. F. Veklych. O. M. Adamenko, O. L. Alexandrovskyi, G. I. Denisyk. S. P. Pozniak and I. Y. Papish in their work "Soilarchaeological research of late Holocene black soils" define soil research and geochronological analysis of buried soils of archeological monuments as those that allow paleogeographic conditions reconstructing as well as reproducing of the evolution of soil cover at all stages of the Holocene [1]. In the monograph "Soils of Trojan shafts" by J. M. Matviishina and Y. M. Dmitruk genetic properties, problems and patterns of evolution of Holocene soils of beligerative complexes are considered in the context of evolutionary and ecological-genetic analysis [2]. A detailed analysis of the genesis of Holocene fossil soils using a geoarchaeological approach is presented in the works of S. P. Karmazinenko, S. P. Doroshkevych, A. S. Kushnir [3-4]. Timing and diversity of evolutionary development of Holocene soils in order to reconstruct the conditions of the past is considered in the works of O. G. Parkhomenko [5]. Buried soils of archeological monuments are considered in a number of works by foreign scientists S. Khamnueva-Wendt, H-R. Bork, F. Kurbanova, M. J. Storozuma, Z. Qin [6-8].

\section{Research materials}

The Holocene soils of the beligerative complexes of the Kamianets-Podilskyi Fortress are represented by naturally anthropogenic soils called urborendzins. Rendzins as soil-forming rocks contain a significant amount of calcium carbonates, which have a unique effect on the soil-forming process and, as a rule, give them properties that differ significantly from the properties of zonal climatic soils. Therefore, rendzins are considered and classified as typical intra zonal biolithogenic soils with mandatory presence of $\mathrm{CaCO}_{3}$ in the soil-forming rock [9].

Depending on the composition and properties of soil-forming rocks, rendzins are divided into two groups: rendzins, i.e., soils formed on the weathering crust of dense carbonate rocks, such as chalk, limestone, marl; pararendzins, i.e. soils formed on loose carbonate rocks, such as loams, clays, moraines [10]. Thus, the ontogenesis of urborendzins occurs under the influence of eluvial and biogenicaccumulative processes (accumulation of litter, decalcification, decarbonation), but the dominant are anthropogenic and pedoturbation processes (erosion, mixing, burial) [11].

The geographical location of the fortress territory and its associate beligerative infrastructure is due to the tactical advantage of the combination of slope exposures at the confluence of the Smotrych River and its tributary - the Dibruha River. Morphological features of the relief and genetic combination of local landscapes are due to the peculiarities of split tectonics and lithological basis. They influenced the activity of erosion, the formation of the hydrological network, phytocolonization and the formation of natural soil cover.

The vegetation of the beligerative complex is represented by a transformed meadow-steppe formation. In geobotanical terms, the study area is located within the South Polish-Western Podolsk subprovince of deciduous forests and meadow steppes [12].

According to palynological studies, in particular spore-pollen analysis, the vegetation of this area during the Holocene till nowadays has not changed significantly its boundaries, but its floristic composition has undergone substantial changes [13]. The natural vegetation is preserved by fragments of meadow steppes and steppe meadows, the species composition of which in the anthropogenically altered formation is represented by only a small number of endemic species: schivereckia podolica, cypripedium calceolus L., fritillaria montana and stipa pennata.

The group is based mainly on neophytes: elymus repens, amaranthus caudatus, phleum pratense, dáctylis glomeráta, medica gofalcata, brassica napus, amaranthu sretroflexus, malva sylvestris, bgerteroa incana, stellaria media, hyoscýamus níger prevail. Ruderal forms are presented by artemisia vulgaris, echinops sphaerocephalus, conium maculatum.

The tectonic structure is characterized by a network of splits, being oriented sublatitudinally and submeridionally, determined the development of watercourse valleys. Block activity at the split intersection caused the formation of an omega-shaped meander within the historical part of KamianetsPodilskyi and the emergence of an erosion remnant 
within the modern castle bridge. This remnant necessitated the strategic need to build fortifications to protect it as a direct route to the city. The relief here is due to the peculiarities of the lithological basis. The slopes and inner terraces of the canyon-like parts of the valleys are an erosive cut in the Silurian sediments. The supra-canyon part (fourth terrace) is an accumulative-erosion relic of the hydro network, which existed before the formation of Smotrych and was partially modified by it later.

The stratigraphic structure of the Silurian base has a monoclinic occurrence with a southwestern slope of the layers, which is noticeable even on visual inspection of rocky slopes. It is partly complicated by block microlifts within the old town. The composition of rocks is sedimentary carbonate sediments (Fig. 1).

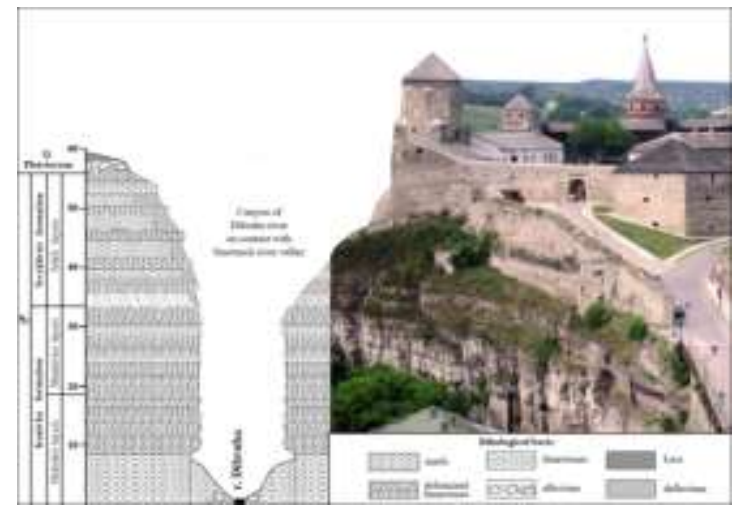

Fig.1. Lithological basis of the beligerative complex of Kamianets-Podilskyi fortress (developed by the authors)

They reflect the transgressive event of the beginning of the late Silurian with its natural changes. According to the local stratigraphic scale, they are united into the Malynovetskaya series, which is represented here by (formations): Konivska and Tsvyklivetska [14]. Konivska beds are composed of shallow coastal deposits. In the lower riverbed part there are bundles of domerites in form of lagoons with periodic drying, which turn gradually in the upward section direction into reef dolomitized limestones with numerous visible remains of favositides, tabulates and crinoids. These deposits are combined into Holoskivska subformation. There is a clear cut metabentonite horizon on its confining bed, which separates the Shutnivska subformation from deeper reef deposits. In the canyon this part forms a visually monolithic lower part with steep rocky slopes

The Tzvyklivets formation is represented by the alternation of powerful (up to 1,5 m) bundles of marls and domerites formed in deeper water environment in comparison with the Konivska formation conditions. They are united in the Sokil subformation and morphologically form a steep slope where accumulative deluvial areas alternate with indentations of native rocks. Accumulation areas are fixed by rocksteppe vegetation and demarcated by shrub strips. These deposits are the basis of the beligerative complex of the fortress.

On the opposite bank of the Dibruha River the thickness of the Sokil deposits reaches $20 \mathrm{~m}$. They are covered with ancient alluvium of problematic origin.
These are mainly transit silicate rocks, including sand and well-rolled jasperoids from the Carpathian region, weakly rolled fragments of Cretaceous spongilites from the Zbruch-Zhvanchytskyi watershed, as well as pebbles of local rocks. The structure of their occurrence does not coincide with the current configuration of the Smotrych river valley, reflecting the relict river network and the initial stages of the canyon part of the valley laying. The alluvium is covered with loess-like loams, the capacity of which increases with remoteness from the canyon parts.

The beligerative complex of the KamianetsPodilskyi Fortress is located on the Sokil lithological basis. The eroded surface forms here a system of steps, bundles of tiled limestones. Their hypsometric levels decrease from the complex of the new fortress to the castle bridge. These rocks have a lumpy structure, with numerous organic remains. Due to the interaction with open air dark gray color of the fresh surface is covered with a light yellow oxidation layer up to $0,5 \mathrm{~cm}$. This material is mostly used as a building material for fortress buildings owing to convenience of use (layers are broken by a system of cracks that form almost rectangular blocks that can be used directly for construction).

Lumpy limestones are separated by layers of marls with its thickness from 0,4 to $1,2 \mathrm{~m}$. It is a fresh surface of light gray color with a blue tint (blue stone). The primary structure is a massive polydetrite structure that becomes shale (less) in a strict sense during one season of interaction with the environment. It leads to easy and rapid mechanical destruction of the rock to the clay fraction. In the structure of the slope, these layers correspond to areas of niches covered with deluvial-eluvial material and reflected by strips of rock-steppe phytocenoses. Blocks of such rocks are used in the reconstruction of fortress buildings (walls). They are visually identified by erosion and shedding without much effort.

The leveled areas of the root surface of the Sokil formation (the surface of limestone packs) are covered with carbonate eluvium and less-loams. The long stage of infrastructural development of the fortress complex has led to the accumulation of building material here, which is similar structurally to eluvium.

Taking into account naturally anthropogenically altered biolithogenic factors of urborendzins formation, influencing their genetic features within the studied beligerative complex, it should be noted that they are characterized by significant variability of soil profile capacity, morphological features, physicochemical features and the presence of buried horizons. The best general research of soil evolution is revealed in the studies of V. A. Kovda and B. G. Rozanov (Fig. 2). They indicate that the soil during ontogenesis undergoes changes due to the weakening or intensification of certain factors of soil formation, which do not allow its diagnosing on the basis of previously known properties. This indicates the evolutionary transition of soils to another stage of their development [10]. Due to the significant variability and violation of natural factors of soil formation, the case of ontogenesis of the studied soils is quite 
complex.

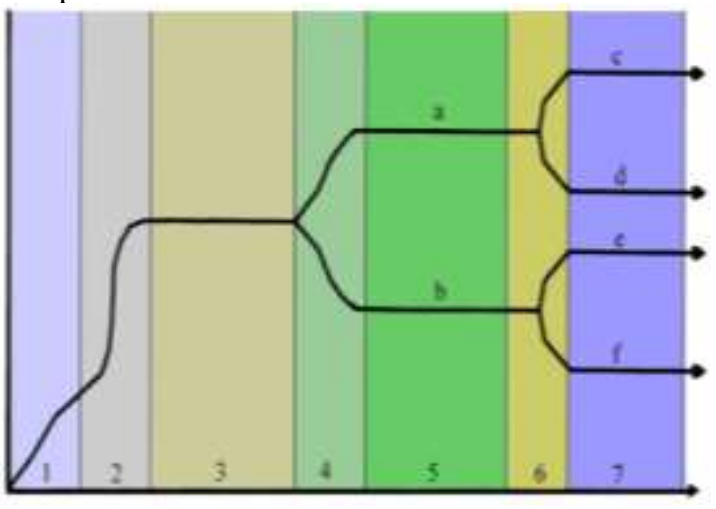

Fig. 2. General scheme of evolutionary sequence of stages and phases of soil formation (modified by the authors) [10]. 1 - initial stage; 2 - perfect stage; 3 - permanent stage; 4 - soil evolution in the "a or b" direction; 5 - permanent stage II (a or b); 6 - new evolution of soil in the c, d, e or f direction; 7 - permanent stage III (c, d, e or f)

They should be taken outside the dominant direction of evolution because they are based on the provisions of the evolutionary paradigm of soil formation. In fact, like most soils formed in the holocene, such soils are polygenetic, and their evolution, in general, should be called phylogeny. Polygenetic soils have several alternating ontogenesis (Fig. 3).

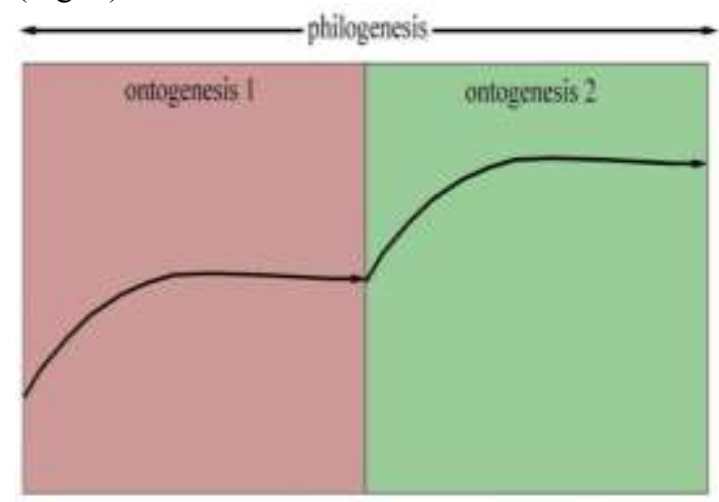

Fig. 3. The ratio scheme of ontogenesis and phylogeny of polygenetic soils (modified by the authors) [15]. Ontogenesis 1 - predominance of natural soil formation processes; ontogenesis 2 - predominance of anthropogenic influence and pedoturbation processes.

The initial stages of the evolution of the urborendzins of the beligerative complex of the Kamianets-Podilskyi fortress proceeded in the formation of typical rendzins. The initial stage is obviously characterized by the dominance of microprocesses of transformation and transfer of substances within the biological cycle with the participation of microbacterial and proactinomycete forms of radial fungi with the decomposition of primary and secondary minerals and the formation of chelates.

Perfect stage is accompanied primarily by the accumulation of organic matter with a decrease in the role of actinomycetes and their subsequent replacement by bacteria, fungi and lichens, which destroy carbonate rocks and primary minerals and thus cause the formation of primary fine soil with the onset of humus accumulation. Then, the development of the grass cover begins with the increase of the fine soil. Significant carbonate content of the parent rock $(25,75$ $\%$ - $40,21 \%$ ) together with grassy vegetation contributed to the intensive development of the sod process of soil formation, which was accompanied by a significant accumulation of humus.

Further evolutionary development is associated with the formation of a beligerative complex, anthropogenic transformation of natural soils, changes in their qualitative and quantitative characteristics, backfilling, burial, mixing and formation of constructional soils. As a result of anthropogenic transformation, intrasoil pedoturbation processes also take place. In order to study in detail the morphogenetic features of the current state of natural and anthropogenic soils, i.e. urborendzins and constructional soils, complex soil and geographical studies were conducted. As a result of research, four key areas of beligerative structures are laid down, which differ in functional purpose and period of formation. Soil sections (1-Dt, 3-Wc) were laid within the key areas and clearings of soils of vertical wall anthropogenic outcrops $(2-\mathrm{Nb}, 4-\mathrm{Ad})$ were made. When choosing the place for laying the sections, the following were used: the plan-scheme of the territory of the museum-reserve "Kamyanets-Podilsky State Historical Museum-Reserve" (scale 1: 1000); largescale topographic map (scale 1: 10000); materials on geomorphology, geological and tectonic structure, hydrogeology and historical and local lore archival materials of the museum-reserve.To diagnose the objects of study and their nomenclature the classification of the FAO (WRB) [16] in combination with the substrate-functional classification of anthropogenic soils by O. B. Vovk and profile-genetic classification by M. M. Stroganova [17] was used.

The designation of genetic horizons is carried out according to the system of indices proposed by academician O.N. Sokolovskyi, with additions proposed by S. P. Pozniak and A. A. Kyrylchuk in combination with the classification developed by M. M. Stroganova [17-18]. The colors of genetic horizons were determined by the Mansell scale [19]. Genetic profiles at the present stage of evolution of Holocene soils of the beligerative complex have the following features: significant variability of morphological elements of the soil in the vertical and horizontal directions; the presence in the profile of the studied soils of day urborendzins, constructional soils, buried horizons of urborendzins of natural and anthropogenic origin, buried fragments of zonal soil types and buried soils of Chornoliska and Trypilska cultures. Within the entire thickness of the profile of the studied soils there is an eluvium of soil-forming rock which is represented by fragments of different shapes, sizes as well as fine carbonate material. Also earth cover contains a significant number of separates of different ages (inclusions), artifacts belonging to different cultural layers.

Constructional soils are characterized by a mosaic profile, spatial heterogeneity of structure and color. The nature and form of transitions between horizons 
indicate the repeated anthropogenic impact on them. The low content or absence of in the layers of constructional soil indicates their bulk nature and leaching of carbonates due to the washing regime (Fig. 4).

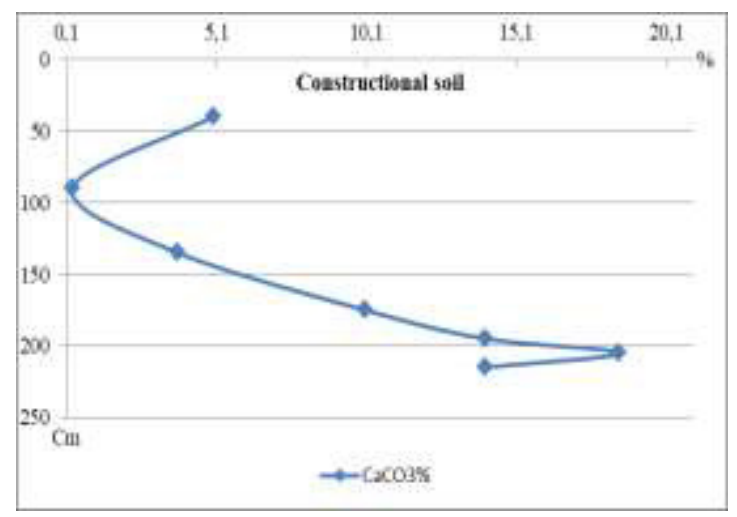

Fig. 4. Graph of $\mathrm{CaCO}_{3}$ content and distribution in the constructional soil (Section 3-Wc is laid on the main shaft of the western curtain near its south-western wall (Geographic coordinates of $48^{\circ} 40^{\prime} 27.03$ " N w. and $26^{\circ} 33^{\prime} 36.25^{\prime \prime}$ east. e.))

Comparing the data on the content of absorbed $\mathrm{CaCO} 3$ urborendzin, we observe the process of decalcification with the removal of carbonates downward the profile in modern urborendzins ((Hcau) $0,79 \%$ and (Hpcau/a1) $0,38 \%$ ) and, conversely, the accumulation of carbonates in buried urborendzins of the Trypillia period (Fig. 5.).

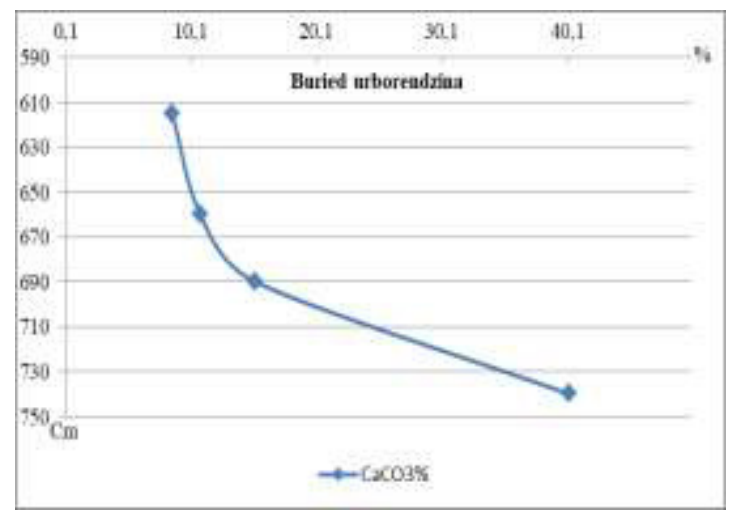

Fig. 5. Graph of $\mathrm{CaCO}_{3}$ content and distribution in buried urborendzin (clearing of anthropogenic 2-Nb outcrop $770 \mathrm{~cm}$ high at a distance of 10 meters eastward from the casemated transition from Rozhanka tower to Pilna gate (Geographic coordinates of $48^{\circ} 40^{\prime} 26.13^{\prime \prime} \mathrm{N} \mathrm{w}$. and $26^{\circ} 33^{\prime} 45.62$ " east. e.))

The humus-accumulative horizon of modern shortprofile urborendzins (Hcau) has a lumpy-grained structure and a thickness from $25 \mathrm{~cm}$. In the buried structure $50-60 \mathrm{~cm}$ thickness is oppressive, nutprismatic (Fig. 6.). According to the results of laboratory analyzes, it was found that with the content of total humus from $3,41 \%$ to $3,59 \%$ in the horizon (Hcau) of diurnal and $1,09 \%$ in the horizon [Hca / a1] of buried urborendzins soil belongs to a small $(<3 \%)$ and medium humus $(3-5 \%)$. The degree of humification of humus-accumulative horizons, both surface and buried, is mostly very high with fluctuations from $76,7 \%$ in the buried Trypillia soil to $34,4 \%$ in short-term modern urborendzins.

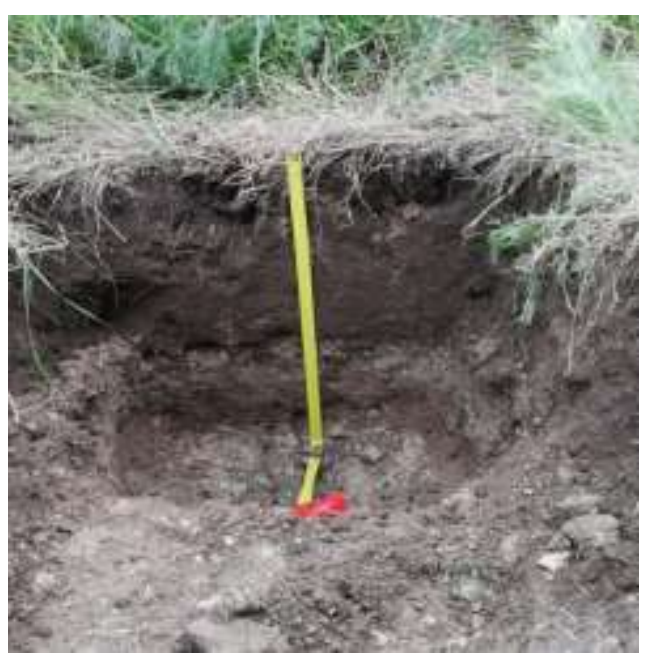

Fig. 6. Photo of the morphology of the soil section 1-Dt (located on the terrace of the upper open part of the "Day Tower", laid on the terrace of the stone floor in the upper part of the "Day Tower" at a distance of 1.5 meters from the inner edge of the wall in a northwesterly direction. Geographic coordinates of $48^{\circ} 40^{\prime} 25.44 \mathrm{~N}$ w. and $26^{\circ} 33^{\prime} 42^{\prime} 97^{\prime \prime}$ east. e.)

The type of humus is mainly humate in the upper part of the profile and fulvate-humate in the transitional and buried horizons. The reaction of the soil solution of urborendzins, both buried and diurnal, is slightly alkali ( $\left.\mathrm{pH} \mathrm{H}_{2} \mathrm{O} 7,57-7,98\right)$, and alkali in the soil-forming rock $\left(\mathrm{pH} \mathrm{H}_{2} \mathrm{O} 8,48-8,65\right)$.

\section{Conclution}

Summing up the study, we note that the study of the genesis of Holocene soils of beligerative complexes is of current concern both in Ukraine and in the whole world.

Kamenets-Podolsky Fortress is a durable selfregulating military fortification beligerative landscape complex of slope type. Located in the canyon part of the valley of the river Smotrych. The peculiarity of this beligerative complex is that on a small area $(\approx 4.5$ hectares) there are various defensive structures from the XIII-XIV centuries to the time of the Commonwealth of the XVII-XVIII centuries and the Russian Empire of the XVIII-XX centuries. The surrounding area is protected for a long time and is not subject to active anthropogenic impact The Holocene soils of the Old Castle of Kamianets-Podilskyi are represented by naturally anthropogenic soils urborendzins and constructional soils. Ecological and geographical conditions of their genesis (ontogenesis) are quite modified. The lithogenic basis of the beligerative complex is a dense sedimentary rock of sokil sediments. Vegetation is represented by a transformed meadow-steppe formation. The studied soils are polygenetic with a rather complex phylogeny, divided by the beginning of the construction of the beligerative complex into, at least, two successive ontogeneses. For a long time soils have been evolving naturally in form of typical rendzin, but have 
undergone quantitative and qualitative changes due to intensive anthropogenic activity. The genetic profile of soils is characterized by significant variability of morphological traits, the presence of eluvium of soilforming rocks in the entire soil layer. The genetic (ontogenetic) features of the Holocene soils of the Kamianets-Podilskyi Fortress together with the elementary soil formation processes largely depend on their lithological composition, which directly affects the development of the soil profile. Therefore, to study the processes of formation, development and dynamics of the investigated soils, it is necessary to apply lithologically oriented research methods and trends, taking into account the determining role of the anthropogenic factor. The soils of Kamianets-Podilskyi Fortress (modern and buried) are an integral part of historical and cultural lands and should be protected, as they contain information about the evolution of the territory and ways of its use. Thus, soil profiles of beligerative complexes are heterogeneous (formed by different elementary soil processes that operate with different intensity and spatial localization), and heterochronous (different parts and features of the profile were formed at different times). Accordingly, some morphological features of the soil are the result of modern processes, while others are of ancient processes that corresponded to another combination of soil formation factors, and currently either absent or have much lower intensity, and their detection allows reconstruct paleogeographic conditions.

\section{Reference}

1. S. P. Poznyak, I. Y. Papish, Soil-archaeological research of chernozems of the late Holocene. Bul. Inst. Arch. 3, 8-16 (2008)

2. Y. M. Dmytruk, Zh. M. Matviishyna, I. I. Slyusarchuk. Soils of Trojan shafts: evolutionary and ecological-genetic analysis (Ruta, Chernivtsi, 2008), p. 228

3. Zh. M. Matviishyna, S. P. Doroshkevych, A. C. Kushnir, Reconstruction of landscapes lifetime Trypillya culture based on paleopedological research. Bul. Lv. Univ. Ser. Geo. 48, 107-115 (2014)

4. Zh. M.Matviishyna, S. P. Karmazynenko, S. P. Doroshkevych, O. V. Matsibora, Paleogeographical preconditions and factors of changes in human living conditions in the territory of Ukraine in Pleistocene and Holocene. Ukr. Geol journ. 1, 19-30 (2017)

5. Zh. M. Matviishyna, O. G. Parkhomenko, Research of Holocene soils on the territory of the National Historical and Cultural Reserve "Hetman's Capital" in Baturyn in Chernihiv region. Sc. Bul. Chern. Univ. 824 (2020)

6. F. Kurbanova, T. Puzanova, O. Rudenko, G Starodubtsev, Dataset on the soils of Medieval archaeological monuments in the forest-steppe zone of the East European Plain. Dat. in Bri. 30 (2020)
7. M. J. Storozum, Z. Qin, Y. V. Wang, H. Liu, Buried soils as archives of paleo-pollution in the North China Plain. Anthropo. 31 (2020)

8. S. Khamnueva-Wendt, A. V. Mitusov, J. Wendt H. Bork, Classification of buried soils, cultural, and colluvial deposits in the Viking town Hedeby. Geoarchaeol. 35, 313-337 2020

9. F. Dushofur. Fundamentals of Soil Science: Soil Evolution (Experience in Studying the Dynamics of Soil Formation (Progress, Moscow, 1970), p. 592

10. V. A. Kovda, B. G. Rozanov (ed.), Soil Science. Soil and soil formation. (Higher. Shk, Moscow, 1988), p. 400

11. A. A. Kyrylchuk, Agrogenic transformation of rendzins in the Western region of Ukraine in the conditions of intensive farming. Prob. Agrochem. Eco. 1, 36-42 (2014)

12. Y. P. Didukh, Y. R. Shelyag-Sosonko, Geobotanic region of Ukraine and surrounding areas. Ukr. Bot. Jor.. 1, 6-17 (2003)

13. V. V. Menderetsky, G. V. Chernyuk, I. P. Kasiyanyk, Natural rhythms of formation of Smotrytsya canyon according to palynological analysis of deposits of low terraces and floodplain of middle Dniester. Bul. Kam-Pod. Nat. Univ. 4 85-97 (2019)

14. P. F. Gozhuk (ed.), Stratigraphy of the Upper Proterozoic and Phanerozoic of Ukraine (IGN NAS of Ukraine. Logos, Kyiv, 2013), p. 638

15. E. M. Samoilova, Y. S. Tolchelnikov, Evolution of soils. (MSU, Moscow, 1981), p 81

16. IUSS Working Group WRB, World Reference Base for Soil Resources 2015. (World Soil Resources Reports 106, FAO, Rome, 2015), 192 p.

17. M. N. Stroganova, M. G. Agarkova,. Urban soils: experience of study and taxonomy on the example of soils in the southwestern part of Moscow. Pochv. 7, 16-24 (1992)

18. V. V. Harbar, S. P. Poznyak, Genesis and properties of rendzinas of the Podilski Tovtry. Pol. Jour. Soil. Sc. 48, 229-240 (2015)

19. A. Munsell, Munsell soil color charts. (MD: Munsell Color Co, Baltimore, 1994), p. 16 